\title{
Physiological calf responses to increased chromium supply in summer
}

\author{
M. Yari, ${ }^{*}$ A. Nikkhah, ${ }^{*}{ }^{1}$ M. Alikhani, ${ }^{*}$ M. Khorvash, ${ }^{*}$ H. Rahmani, ${ }^{*}$ and G. R. Ghorbani ${ }^{*}$ \\ ${ }^{*}$ Department of Animal Sciences, Isfahan University of Technology, Isfahan 84156 Iran \\ †Department of Animal Sciences, University of Zanjan, Zanjan 313-45195 Iran
}

\section{ABSTRACT}

The primary objective was to determine pre- and postweaning calf physiological responses to increased Cr supply under high ambient temperatures. In a randomized complete block design, 24 neonate Holstein calves $(\mathrm{BW}=41.5 \pm 1.9 \mathrm{~kg})$ were grouped based on sex and randomly assigned to 3 treatments within each group. Treatments included either no supplemental $\mathrm{Cr}$ (control), $0.02 \mathrm{mg}$ of supplemental $\mathrm{Cr} / \mathrm{kg}$ of $\mathrm{BW}^{0.75}$, or $0.04 \mathrm{mg}$ of supplemental $\mathrm{Cr} / \mathrm{kg}$ of $\mathrm{BW}^{0.75}$. The average temperature-humidity index was 77 during the study. Chromium was provided as a commercial product in whole milk for preweaning calves and in a starter concentrate for postweaning calves. Calves were weaned at $1 \mathrm{~kg}$ of daily calf starter intake lasting for 6 consecutive days. A glucose tolerance test was conducted on d 25 postweaning. Treatments had no effects on preweaning dry matter intake, feed conversion ratio, average daily gain, and weaning age. Chromium decreased dry matter intake in postweaning calves; however, it did not affect growth and feed conversion ratio. Chromium lowered respiration rate at wk 5 without affecting fecal score and rectal temperature. Preweaning serum cortisol concentrations were altered by a 3 -way interaction of $\mathrm{Cr}$ dose with calf sex and age. Preweaning serum glucose showed week-dependent increases by Cr. Serum insulin, urea, albumin, total protein, triiodothyronine, and thyroxin concentrations through weaning were not affected. The increasing $\mathrm{Cr}$ doses caused quadratic declines in serum thyroxin on d 21 postweaning, whereas blood triiodothyronine declined only with the higher $\mathrm{Cr}$ dose. Serum NEFA remained unchanged, but BHBA decreased by $\mathrm{Cr}$ in male calves on $\mathrm{d} 21$ postweaning. The glucose tolerance test revealed linear reductions in area under insulin curve between 0 to 90 and 0 to 120 min after glucose infusion, suggesting improvements in peripheral insulin efficiency. Sex-dependent responses to $\mathrm{Cr}$ were observed for serum total protein and albumin concentrations at $21 \mathrm{~d}$ postweaning. Overall,

Received July 14, 2009.

Accepted May 26, 2010.

${ }^{1}$ Corresponding author: nikkhah@znu.ac.ir results indicate that in summer, increased dietary $\mathrm{Cr}$ supply can benefit postweaning insulin metabolism, alter preweaning blood cortisol and glucose levels, and reduce respiration rate and may have only minor effects on calf growth.

Key words: chromium, dairy calf, summer, physiology

\section{INTRODUCTION}

Chromium is required for insulin metabolism and, thus, for optimum essential nutrients uptake by peripheral cells. It is involved in the amplification of insulin signaling to maintain the active conformation of insulin receptors and facilitate cell glucose entry (Anderson, 1987; NRC, 1997). Chromodulin is a protein consisting of glycine, cysteine, aspartate, and glutamate that binds with high affinity to 4 chromic ions (Vincent, 2000, 2001). Positive physiological and production responses to supplemental $\mathrm{Cr}$ are perceived to depend on the presence of stressors, such as transportation (MoonsieShageer and Mowat, 1993; Mowat et al., 1993), early lactation (Subiyatno et al., 1996; Nikkhah et al., 2010), and high ambient temperatures and metabolic pressures (Nikkhah et al., 2010).

Earlier research with stressed feeder calves has demonstrated positive DMI and growth responses to supplemental Cr (Moonsie-Shageer and Mowat, 1993; Mowat et al., 1993). Because the reticulorumen is not well developed and glucose is absorbed in small amounts in young and growing ruminants compared with adult ruminants, the importance of insulin to glucose and AA homeostasis would differ between calves and fully grown ruminants. Evidence exists that milk-fed calves develop a relative resistance to insulin as they age, resulting in altered insulin action and glucose use by peripheral tissues (Hostettler-Allen et al., 1994; Hugi et al., 1997). If so, Cr supply can play a role in efficient nutrient turnover. In addition, because of the much greater contents of fat and protein versus carbohydrates in milk compared with dry feed, physiological responses to $\mathrm{Cr}$ are hypothesized to be different during pre- and postweaning periods.

As in many other parts of the world, in central Iran the temperature-humidity index (THI) can reach up 
to 83 from May through September. The THI of 78 to 79 and $\geq 83$ are considered as moderate and severe degrees of stress, respectively, for dairy calves (Coleman et al., 1996). High ambient temperatures (AT) may reduce feed intake and cause physiological changes that increase Cr requirements (Nikkhah et al., 2010). AlSaiadi et al. (2004) reported that supplemental Cr in diets of dairy cows under AT (e.g., THI of 78) improved DMI and milk yield. We have recently found that increased Cr supply to cows undergoing coincident metabolic pressures of early lactation and high AT improved insulin efficiency, feed intake, and milk energy output (Nikkhah et al., 2010). It is unexplored whether and how enhanced Cr status can affect metabolism and performance of conventionally milk-fed dairy calves under high AT. Our primary objective was to determine the effects of increased Cr supply on feed intake, growth, respiration rate, and blood levels of metabolites and hormones of Holstein calves from birth through $3 \mathrm{wk}$ postweaning in summer. An additional objective was to establish $\mathrm{Cr}$ effects on peripheral tissue response to increased Cr supply by conducting a glucose tolerance test (GTT) in postweaning calves.

\section{MATERIALS AND METHODS}

\section{Experimental Design, Calves, and Treatments}

Twenty-four neonate Holstein calves $(\mathrm{BW}=41.5 \pm$ $1.9 \mathrm{~kg}$; mean $\pm \mathrm{SE}$ ) born at the calf-raising facilities of the Lavark Research Station (Isfahan University of Technology, Isfahan, Iran) were used in a randomized complete block design from May to July 2007. Calves were reared conventionally, receiving colostrum and transition milk at $10 \%$ of $\mathrm{BW}$ for $3 \mathrm{~d}$ and whole milk from d 4 until weaning. Calves received $2 \mathrm{~L}$ of whole milk twice daily at 1400 and $2030 \mathrm{~h}$, with ad libitum access to a starter concentrate (Table 1) and fresh water. Calves were grouped by sex and assigned randomly to 3 treatments within each group such that each treatment was given to 5 female and 3 male calves. Chromium was added as a Cr-Met supplement (with a minimum concentration of $1,000 \mathrm{~g} / \mathrm{kg}$ of $\mathrm{Cr}$ from a chromium-Lmethionine complex; Zinpro Co., Eden Prairie, MN) to whole milk until weaning and to the calf starter during the postweaning period to supply either $0,0.02 \mathrm{mg}$ (medium dose), or $0.04 \mathrm{mg}$ (higher dose) of supplemental $\mathrm{Cr} / \mathrm{kg}$ of $\mathrm{BW}^{0.75}$. Upon separation from the dam, calves were transferred to individual hutches $(1.5 \times 1.1$ $\times 1.2 \mathrm{~m}$ ) bedded with clean wheat straw during the preweaning phase and with wood shavings during the postweaning phase. The individual hutches were made of metal and cement and located outdoors. The hutches had a roofed area $(1.2 \times 2.1 \mathrm{~m})$ to protect the calf from
Table 1. Feed ingredients and chemical composition of the calf starter (DM based)

\begin{tabular}{lc}
\hline Item, \% unless noted & Value \\
\hline Ingredient & \\
Ground barley grain & 20.0 \\
Ground corn grain & 34.4 \\
Solvent soybean meal & 34.0 \\
Wheat bran & 6.0 \\
Alfalfa meal & 2.0 \\
Mineral and vitamin supplement ${ }^{1}$ & 0.5 \\
Dicalcium phosphate & 1.5 \\
Bicarbonate sodium & 1.0 \\
NaCl & 0.5 \\
Chemical composition & \\
DM & 94.0 \\
CP & 21.6 \\
ADF & 7.0 \\
Ether extract & 3.3 \\
Ash & 5.0 \\
ME ${ }^{2}$ Mcal/kg & 2.9 \\
\hline
\end{tabular}

${ }^{1}$ Contained per kilogram of supplement: 250,000 IU of vitamin A, $50,000 \mathrm{IU}$ of vitamin D, 1,500 IU of vitamin E, $2.25 \mathrm{~g}$ of Mn, $120 \mathrm{~g}$ of $\mathrm{Ca}, 7.7 \mathrm{~g}$ of Zn, $20 \mathrm{~g}$ of P, $20.5 \mathrm{~g}$ of Mg, $186 \mathrm{~g}$ of Na, $1.25 \mathrm{~g}$ of Fe, $3 \mathrm{~g}$ of S, $14 \mathrm{mg}$ of Co, $1.25 \mathrm{~g}$ of $\mathrm{Cu}, 56 \mathrm{mg}$ of I, and $10 \mathrm{mg}$ of Se.

${ }^{2}$ Calculated from NRC (2001).

direct sunlight and rainfall and had a rear window $(0.42$ $\times 0.42 \mathrm{~m}$ ). Individual hutches were entirely cleaned and disinfected daily using Sovlorin Cetrimide-C (1.5\% wt/ vol clorohexidin glucoronate and $15 \% \mathrm{wt} / \mathrm{vol}$ cetrimide; Damloran Co., Boroojerd, Iran). Beddings were renewed as required.

Orts were removed and fresh starter was offered daily at $1400 \mathrm{~h}$. All calves were weighed on d 4 of age and once weekly thereafter for the entire experiment. On the last day of every week, the amount of supplemental $\mathrm{Cr}$ for the following week was adjusted based on the most recent BW record. Calves were weaned off milk abruptly when they consumed $1 \mathrm{~kg}$ of the calf starter for 6 consecutive days. After weaning all calves had ad libitum access to the same starter concentrate (Table 1). A week past weaning, calves were offered chopped alfalfa hay (Table 2) with unlimited access to fresh water. Orts were removed at $1400 \mathrm{~h}$ and fresh chopped alfalfa hay was provided immediately afterward. The starter concentrate and alfalfa were sampled weekly for DM (oven drying at $60^{\circ} \mathrm{C}$ for $48 \mathrm{~h}$ ), ADF (method 973.18; AOAC, 2002), ether extract, and CP (1030 Micro Kjectel Auto Analyzer, method 984.13; AOAC, 2002) analysis. Animals were cared for according to the guidelines of the Iranian Council of Animal Care (1995).

\section{Respiration Rate, Rectal Temperature, and Blood Sampling and Analysis}

During the preweaning period, respiration rate (RR) was measured at $1500 \mathrm{~h} 3$ times weekly, during the 
Table 2. Dry matter based chemical composition of chopped alfalfa hay offered to Holstein calves from wk 1 postweaning

\begin{tabular}{lc}
\hline Chemical composition & \% of DM \\
\hline DM & 86.0 \\
CP & 16.0 \\
ADF & 37.5 \\
Ether ash & 3.0 \\
Ash & 10.0 \\
\hline
\end{tabular}

first $3 \mathrm{~d}$ of each week, by visual observation for 3 separate minutes. Immediately after recording $\mathrm{RR}$, rectal temperature (RT) was recorded using a thermometer (Qingdao Dacon Trading Co. Ltd., Shandong, China) held in the calf rectum for $1 \mathrm{~min}$. Feces were scored for physical shape and consistency $(1=$ firm, $2=$ slightly loose, 3 = loose, 4 = watery; Larson et al., 1977).

Blood samples were taken from the jugular vein at $1500 \mathrm{~h}$ every week up to weaning and on d 21 after weaning in 10-mL tubes (Shandong Weigao Group Medical Polymer Co. Ltd., Weihei, Shandong, China). Blood samples were placed on ice immediately after collection and centrifuged at $4,500 \times g$ for $15 \mathrm{~min}$ at $4^{\circ} \mathrm{C}$ to harvest serum. The serum was preserved $\left(-20^{\circ} \mathrm{C}\right)$ until analysis for metabolites and hormones. Concentrations of insulin, thyroxin $\left(\mathbf{T}_{4}\right)$, triiodothyronine $\left(\mathbf{T}_{3}\right)$, and cortisol were measured using RIA with commercial kits and an automatic gamma counter (BioSource International, Camarillo, CA). Serum total proteins (TP), albumin, urea nitrogen, and glucose were measured using Pars Azmoon kits and associated procedures (Pars Azmoon Co., Tehran, Iran). Globulin concentrations were obtained by deducting albumin from TP. The concentrations of NEFA and BHBA were measured in postweaning blood samples using commercial kits with a Technicon-RA 1000 Autoanalyzer (DRG Co., Marburg, Germany).

\section{Intravenous GTT}

An intravenous GTT was conducted on d 25 postweaning using 12 female and 6 male calves, with 4 females and 2 males per treatment. The GTT was performed following overnight feed deprivation, with unlimited access to water. Calves were fitted with 14-gauge jugular catheters (Narang Medical Ltd., New Delhi, India) and allowed to settle for at least $1 \mathrm{~h}$ before GTT. Glucose was infused as a bolus dose (50\% wt/vol) with $0.3 \mathrm{~g}$ of glucose $/ \mathrm{kg}$ of $\mathrm{BW}$, as described by Kitchalong et al. (1995). Blood samples were collected at $0,+20,+40$, $+60,+90$, and +120 min relative to glucose infusion. After each bleeding, catheters were flushed with $1 \mathrm{~mL}$ of a heparin-saline solution to prevent clotting within catheters and extension sets. The glucose and insulin responses to GTT were evaluated by computing areas under the curve (AUC) during 0 to 60 min, 0 to 90 min, and 0 to $120 \mathrm{~min}$ postinfusion. Catheter maintenance, blood handling procedures, and mathematical procedures used to compute kinetic variables were described elsewhere (Kitchalong et al., 1995).

\section{Climatic Data}

Maximum air temperature $(\mathrm{T})$ and minimum relative humidity $(\mathrm{RH})$ data were obtained from daily reports of Najaf Abad's Meteorological Network Station (Isfahan, Iran) to calculate the THI according to the following formula: $\mathrm{THI}=0.8 \times$ maximum $\mathrm{T}+($ minimum $\mathrm{RH} / 100) \times($ maximum $\mathrm{T}-14.4)+46.4$; García-Ispierto et al., 2006). The average maximum THI during the study was 77 units, which indicates a medium degree of heat stress. It has been suggested that physiological responses to heat overload (e.g., increased maintenance energy expenditure) begin to occur at a THI of 72 (Johnson, 1987).

\section{Statistical Analysis}

Data for initial BW; preweaning, postweaning, and overall ADG, DMI, and feed efficiency; weaning age; and AUC for glucose and insulin of GTT were analyzed as a mixed model with fixed effects of treatment, sex, and treatment $\times$ sex, plus the random effect of calf within sex $\times$ treatment (SAS Institute, 2003). For repeated weekly BW, RR, RT, fecal score, and blood parameters, mixed models with fixed effects treatment, sex, week, treatment $\times$ sex, treatment $\times$ week, sex $\times$ week, and treatment $\times$ sex $\times$ week as well as the random effect of calf within treatment $\times$ sex $\times$ week were used. Two- and 3-way interactions were illustrated in graphs as required. Blood metabolites and hormones for d 21 postweaning were analyzed separately with a model without the effect of time. Where biologically worthwhile and significant, the initial values were included in models as a covariate to further improve the analysis precision. To take into account the unsimilar correlations of the repeated measures on the same subject, mixed models with different covariance structures [e.g., compound symmetry, compound symmetry heterogeneous, autoregressive (1), autoregressive heterogeneous (1), unstructured] were tested to adopt the structure producing least fit criteria (Littell et al., 2006). The autoregressive (1) was found to be the optimum choice (Wang and Goonewardene, 2004). Orthogonal contrasts were used to obtain linear and quadratic trends of treatment effects on response criteria. The PDIFF option of SAS (SAS Institute, 2003) was used to separate means. The significance differences were declared at $P \leq 0.05$ and tendencies were declared at $P \leq 0.10$. 


\section{RESULTS AND DISCUSSION}

\section{DMI, Feed Conversion Ratio, Growth, Fecal Score, RR, and RT}

Preweaning starter intake, milk intake, total DMI, $\mathrm{ADG}$, and BW as well as weaning age were not significantly affected by $\mathrm{Cr}$ (Table 3). As expected, BW increased as calves approached weaning (41.6, 44.5, 46.0, 49.0, 53.4, 58.8, and 65.0 for wk 1, 2, 3, 4, 5, 6, and 7 , respectively; $P<0.001$ ). These data were similar to other studies (Depew et al., 1998; Bunting et al., 2000) with Holstein calves fed Cr-nicotinic acid, Crchloride, Cr-picolinate, or Cr-propionate under normal conditions. However, postweaning starter intake and total DMI exhibited a quadratic response $(P<0.10)$ to $\mathrm{Cr}$ supplementation such that they tended to decrease at $0.02 \mathrm{mg}$ of $\mathrm{Cr}$ but not at $0.04 \mathrm{mg}$ of $\mathrm{Cr} / \mathrm{kg}$ of $\mathrm{BW}^{0.75}$ (Table 3). As a result, similar quadratic trends occurred for average DMI throughout the study $(P=$ 0.11; Table 3). The relatively decreased DMI could be a continual tendency for increased peripheral nutrient use efficiency that would spare further nutrient intake. This explanation, as discussed later, is consistent with improved insulin function by $\mathrm{Cr}$. Male calves had greater preweaning ADG than female calves (0.55 vs. $0.49 \mathrm{~kg} / \mathrm{d} ; P=0.04$ ), suggesting a more efficient tissue accretion in males calves. This is supported by the numerically lower feed conversion ratio (FCR) in males compared with females (1.82 vs. $1.99 ; P=0.11)$. An interaction existed between treatment and sex on FCR $(P=0.09$; Table 3$)$ such that, without $\mathrm{Cr}$ supplementation (2.1 vs. 1.7) and on $0.04 \mathrm{mg}$ of $\mathrm{Cr} / \mathrm{kg}$ of $\mathrm{BW}^{0.75}$ (2.0 vs. 1.7), females had higher FCR than males, whereas on $0.02 \mathrm{mg}$ of $\mathrm{Cr} / \mathrm{kg}$ of $\mathrm{BW}^{0.75}$, females were similar to males (1.9 vs. 2.1). In postweaning ruminants during transportation and early lactation, Cr has had only minor effects (Moonsie-Shageer and Mowat, 1993; Mowat et al., 1993; Subiyatno et al., 1996). In a recent study (Nikkhah et al., 2010) where metabolic pressures of early lactation coincided with high AT, increased dietary Cr supply improved insulin function and milk production. We had hypothesized that increased $\mathrm{Cr}$ supply affects calf metabolism during the development of the internal immune system while expanding the reticulorumen fermentation that will continue after weaning. The possibility exists that the preweaning THI of 77 was not quite severe for the effects of increased $\mathrm{Cr}$ intake on preweaning calf DMI and growth to be very detectable. In addition, despite their increasing growth rate, preweaning calves consume energy at much lower levels above maintenance compared with older calves, heifers, and lactating cows. Moreover, fecal score and RT were natural and similar among groups $(P<0.10$;
Table 4), implying reasonable calf ability to cope with stresses in the current study. These data collectively suggest a limited likelihood of performance response to nutritional treatments when calf health and immunity are not seriously compromised. Coleman et al. (1996) considered THI of 78 to 79 and $\geq 83$ as medium and severe degrees of stress, respectively, for Holstein calves, lending support to growth response under current experimental conditions.

The effect of week was significant for $\mathrm{RR}(P<0.0001$; Table 4 ), being 57.5 times/min at wk 1 compared with $37.9,37.0,38.5,42.2$, and 40 times/min for wk $2,3,4$, 5 , and 6 , respectively, suggesting a more pronounced effect of environmental challenges on calf well-being very early in life shortly after leaving the maternal environment and starting to adapt to external conditions. Consistent with RR, RT was also greater in wk 1 than in following weeks (39.38 vs. 39.26, 39.23, 39.3, 39.11, $39.22,39.15,39.26$, and 39.27 for wk $1,2,3,4,5,6,7$, 8 , and 9 , respectively; $P=0.03$ ). These data were in agreement with the higher fecal score (i.e., more watery feces) at wk 1 and 2 compared with following weeks (2.06 and 2.07 vs. $1.57,1.72,1.49,1.65,1.60,1.51,1.35$ for wk $1,2,3,4,5,6,7,8$, and 9 , respectively). A numerical interaction existed between treatment and week for $\operatorname{RR}(P=0.13$; Table 4$)$ such that at wk 5 calves on $0.02 \mathrm{mg}$ of $\mathrm{Cr} / \mathrm{kg}$ of $\mathrm{BW}^{0.75}$ had lower $\mathrm{RR}$ than control calves (34.1 vs. 48.0 times/min). A lower RR could suggest a moderated effect of high AT on calf health attributed to improved Cr supply.

\section{Blood Metabolites and Hormones and GTT}

Blood concentrations of glucose and insulin and glucose to insulin ratio (G:I) across preweaning weeks were not affected by treatment (Table 5). However, there was a significant treatment $\times$ week effect for blood glucose $(P=0.05)$. At wk 3 , blood glucose tended to be higher $(P=0.08)$ in calves receiving $0.02 \mathrm{mg}$ instead of 0.04 $\mathrm{mg}$ of $\mathrm{Cr} / \mathrm{kg}$ of $\mathrm{BW}^{0.75}$, whereas at wk 4 it was the opposite (Figure 1). At wk 5, blood glucose tended to increase $(P=0.09)$ by providing 0.04 and not $0.02 \mathrm{mg}$ of supplemental $\mathrm{Cr} / \mathrm{kg}$ of $\mathrm{BW}^{0.75}$, whereas at wk $6,0.02$ $\mathrm{mg}$ of supplemental $\mathrm{Cr}$ was enough to increase blood glucose $(P=0.04 ;$ Figure 1$)$. Other reports indicate little effect of $\mathrm{Cr}$ on blood glucose and insulin in calves under normal environments (Kegley and Spears, 1995; Depew et al., 1998). Heat overload may reduce feed intake and increase maintenance expenditure (Mowat, 1997). However, no research has evaluated heat stress effects on glucose and insulin dynamics in calves. AlSaiadi et al. (2004) reported no effects of supplemental $\mathrm{Cr}$ on blood glucose in dairy cattle under mild to medium heat stress $(\mathrm{THI}=78.6)$, although improvements 
Table 3. Effects of increased $\mathrm{Cr}$ supply on feed intake, feed conversion ratio, growth rate, and BW of Holstein calves monitored from d 4 of age until d 21 postweaning

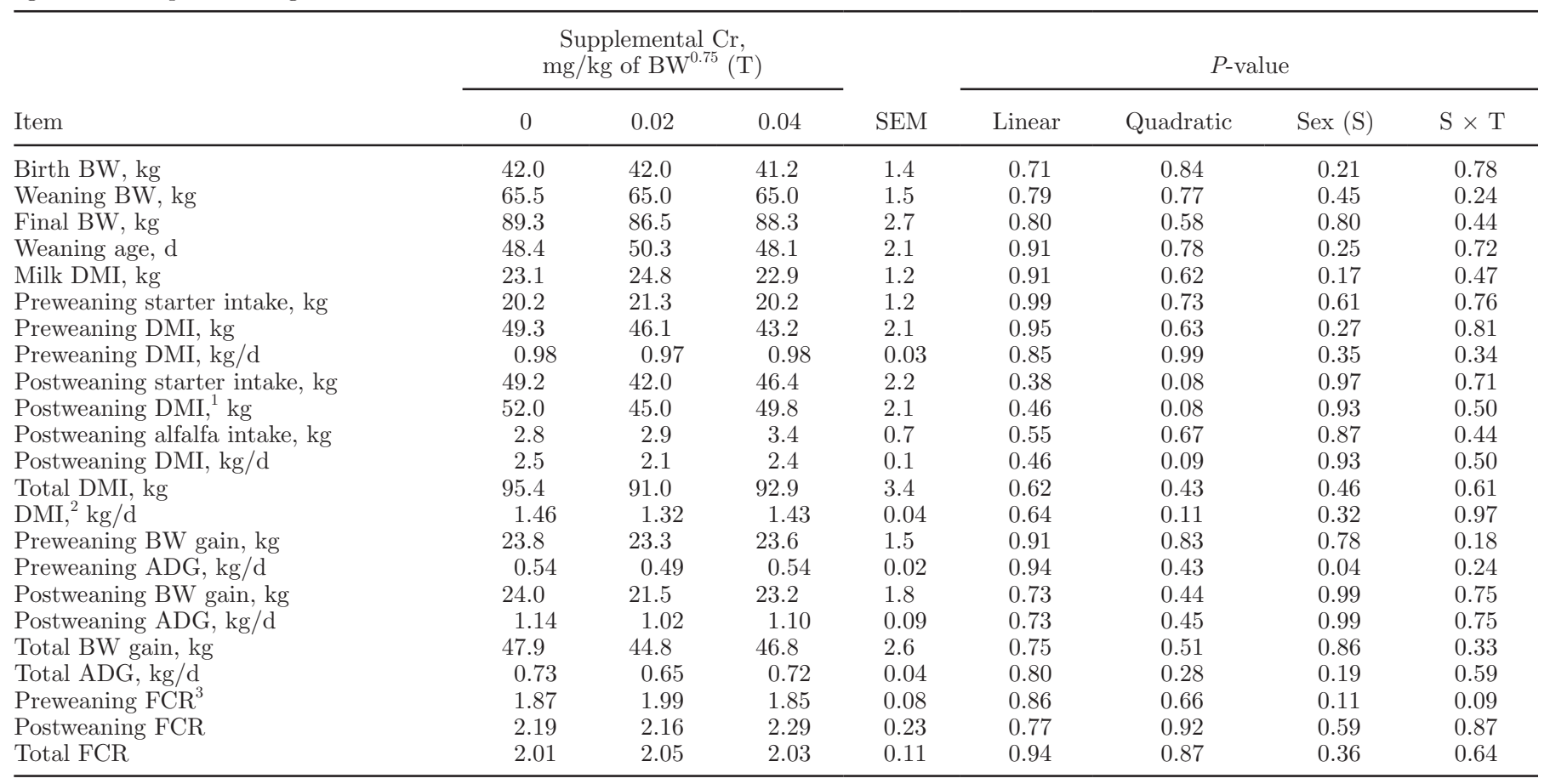

${ }^{1}$ For 0 vs. $0.02, P=0.07$.

${ }^{2}$ For 0.02 vs. $0.04, P=0.07$.

${ }^{3} \mathrm{FCR}=$ feed conversion ratio.

in glucose and insulin metabolism have been found in early-lactation cows under high AT (Nikkhah et al., 2010), periparturient cows (Subiyatno et al., 1996), and laying hens (Sahin et al., 2002). The G:I is an indirect indicator of insulin sensitivity. Data on the effects of $\mathrm{Cr}$ on G:I in ruminants have been contradictory (Subiyatno et al., 1996; NRC, 1997; Kegley et al., 2000; Hayirli et al., 2001). The varying responses may reflect differences in Cr status of the animal, the physiological state of animal, the degree of stress, and form and bioavailability of supplemental Cr. Treatments tended to interact with calf sex on blood G:I in our study $(P=0.09)$. The females (10.3 vs. 13.5 and 12.6) and not males (12.9 vs. 12.8 and 12.6) had a lower G:I when receiving 0.04 $\mathrm{mg}$ vs. 0.02 and $0 \mathrm{mg}$ of supplemental $\mathrm{Cr} / \mathrm{kg}$ of $\mathrm{BW}^{0.75}$. The interactions suggests that $\mathrm{Cr}$ may alter insulin responsiveness or sensitivity in either extracellular or intracellular fashion and that such an effect is at least in part modulated by growth rate because male calves had greater preweaning ADG than females.

Blood glucose and insulin were similar between treatments at $21 \mathrm{~d}$ postpartum (Table 6). The GTT conducted on d 25 postweaning revealed a major novelty that the AUC of insulin during 0 to 90 and 0 to $120 \mathrm{~min}$ after glucose infusion linearly decreased by about $30 \%$ as Cr supply increased (Table 7; $P<0.05$ ). However,

Table 4. Effects of $\mathrm{Cr}$ supplementation on fecal score, respiration rate, and rectal temperature of Holstein calves ${ }^{1}$

\begin{tabular}{|c|c|c|c|c|c|c|c|c|c|c|c|c|}
\hline \multirow[b]{2}{*}{ Item } & \multicolumn{3}{|c|}{$\begin{array}{l}\text { Supplemental Cr, } \\
\mathrm{mg} / \mathrm{kg} \text { of } \mathrm{BW}^{0.75}(\mathrm{~T})\end{array}$} & \multirow[b]{2}{*}{ SEM } & \multicolumn{8}{|c|}{$P$-value } \\
\hline & 0 & 0.02 & 0.04 & & Linear & Quadratic & $\begin{array}{l}\text { Sex } \\
(\mathrm{S})\end{array}$ & $\begin{array}{l}\text { Week } \\
(\mathrm{W})\end{array}$ & $\mathrm{S} \times \mathrm{T}$ & $\mathrm{T} \times \mathrm{W}$ & $\mathrm{S} \times \mathrm{W}$ & $\begin{array}{l}\mathrm{S} \times \mathrm{T} \\
\times \mathrm{W}\end{array}$ \\
\hline Fecal score & 1.77 & 1.55 & 1.69 & 0.10 & 0.61 & 0.27 & 0.39 & 0.0002 & 0.55 & 0.79 & 0.29 & 0.31 \\
\hline Respiration rate, $\min ^{-1}$ & 43.1 & 40.9 & 42.6 & 3.1 & 0.89 & 0.72 & 0.65 & 0.0001 & 0.50 & 0.13 & 0.28 & 0.36 \\
\hline Rectal temperature, ${ }^{\circ} \mathrm{C}$ & 39.2 & 39.3 & 39.2 & 0.06 & 0.64 & 0.27 & 0.70 & 0.03 & 0.95 & 0.64 & 0.75 & 0.32 \\
\hline
\end{tabular}

${ }^{1}$ Respiration rate was measured at $1500 \mathrm{~h} 3$ times weekly (for the first $3 \mathrm{~d}$ of week) by visual observation for 3 separate minutes on each day until weaning. Rectal temperature and fecal score were recorded weekly from wk 1 of age through 3 wk postweaning. Feces was scored for physical shape as follows: 1 = firm, $2=$ slightly loose, $3=$ loose, and $4=$ watery. 
Table 5. Effects of Cr supplementation on blood metabolites and hormones and BW from d 4 of age through weaning of Holstein calves

\begin{tabular}{|c|c|c|c|c|c|c|c|c|c|c|c|c|}
\hline \multirow[b]{2}{*}{ Item } & \multicolumn{3}{|c|}{$\begin{array}{l}\text { Supplemental Cr, } \\
\mathrm{mg} / \mathrm{kg} \text { of } \mathrm{BW}^{0.75}(\mathrm{~T})\end{array}$} & \multirow[b]{2}{*}{ SEM } & \multicolumn{8}{|c|}{$P$-value } \\
\hline & 0 & 0.02 & 0.04 & & Linear & Quadratic & $\begin{array}{l}\text { Sex } \\
(\mathrm{S})\end{array}$ & $\begin{array}{l}\text { Week } \\
(\mathrm{W})\end{array}$ & $\mathrm{S} \times \mathrm{T}$ & $\mathrm{T} \times \mathrm{W}$ & $\mathrm{S} \times \mathrm{W}$ & $\begin{array}{l}\mathrm{S} \times \mathrm{T} \\
\times \mathrm{W}\end{array}$ \\
\hline Glucose, $\mathrm{mg} / \mathrm{dL}$ & 63.5 & 66.0 & 65.4 & 1.8 & 0.47 & 0.34 & 0.95 & 0.008 & 0.19 & 0.05 & 0.30 & 0.76 \\
\hline Insulin, $\mu \mathrm{IU} / \mathrm{mL}$ & 5.9 & 6.0 & 6.2 & 0.41 & 0.57 & 0.63 & 0.87 & 0.03 & 0.53 & 0.16 & 0.25 & 0.94 \\
\hline Glucose:insulin & 12.6 & 13.1 & 11.6 & 0.51 & 0.20 & 0.74 & 0.31 & 0.25 & 0.09 & 0.29 & 0.26 & 0.77 \\
\hline Triiodothyronine, $\mathrm{ng} / \mathrm{dL}$ & 139.4 & 137.6 & 136.0 & 2.6 & 0.38 & 0.43 & 0.89 & 0.39 & 0.73 & 0.78 & 0.84 & 0.81 \\
\hline Triiodothyronine:thyroxin & 26.6 & 27.0 & 26.6 & 0.61 & 0.97 & 0.78 & 0.86 & 0.50 & 0.32 & 0.84 & 0.84 & 0.79 \\
\hline Total proteins, $\mathrm{g} / \mathrm{dL}$ & 8.12 & 7.97 & 8.11 & 0.09 & 0.95 & 0.51 & 0.58 & 0.66 & 0.73 & 0.47 & 0.82 & 0.65 \\
\hline Albumin, $\mathrm{g} / \mathrm{dL}$ & 4.14 & 4.06 & 4.14 & 0.06 & 0.95 & 0.64 & 0.42 & 0.67 & 0.46 & 0.69 & 0.79 & 0.29 \\
\hline Globulins, $\mathrm{g} / \mathrm{dL}$ & 3.98 & 3.91 & 3.96 & 0.06 & 0.80 & 0.52 & 0.97 & 0.72 & 0.93 & 0.18 & 0.93 & 0.40 \\
\hline Albumin:globulins & 1.04 & 1.05 & 1.06 & 0.02 & 0.50 & 0.50 & 0.24 & 0.55 & 0.22 & 0.40 & 0.93 & 0.08 \\
\hline Urea $\mathrm{N}, \mathrm{mg} / \mathrm{dL}$ & 4.61 & 4.85 & 4.52 & 0.19 & 0.73 & 0.80 & 0.59 & 0.23 & 0.28 & 0.86 & 0.36 & 0.75 \\
\hline
\end{tabular}

${ }^{\mathrm{a}, \mathrm{b}}$ Different superscripts within a row indicate statistical significance at $P<0.05$.

differences in AUC for glucose did not reach statistical significance. These data support the hypothesis that increased Cr supply alters insulin efficiency in young calves in summer. The GTT is a practical technique to evaluate Cr status and its involvement with insulin and glucose metabolism in humans and ruminants because $\mathrm{Cr}$ can act to maintain glucose homeostasis through effective insulin secretion (Subiyatno et al., 1996). Similar to glucose in the present study, Kegley et al. (2000) reported no significant effects of $\mathrm{Cr}$ on glucose AUC after a GTT in beef steers. A greater AUC would indicate greater peripheral glucose intolerance, whereas a lower insulin AUC would suggest an improved insulin efficiency or a reduced need for insulin for efficient and timely peripheral glucose uptake (Hayirli et al., 2001). Supplemental Cr during the transition period has improved glucose tolerance and insulin responsiveness (Hayirli et al., 2001). In calves under normal environments, increased $\mathrm{Cr}$ supply has increased insulin response after an insulin challenge (Kegley et al., 2000).

Despite no main effect of treatment, sex, and week per se, their 3-way interaction on blood cortisol concentrations through weaning was significant $(P=0.03)$. As shown in Figure 2, in female calves at wk 2, blood cor-

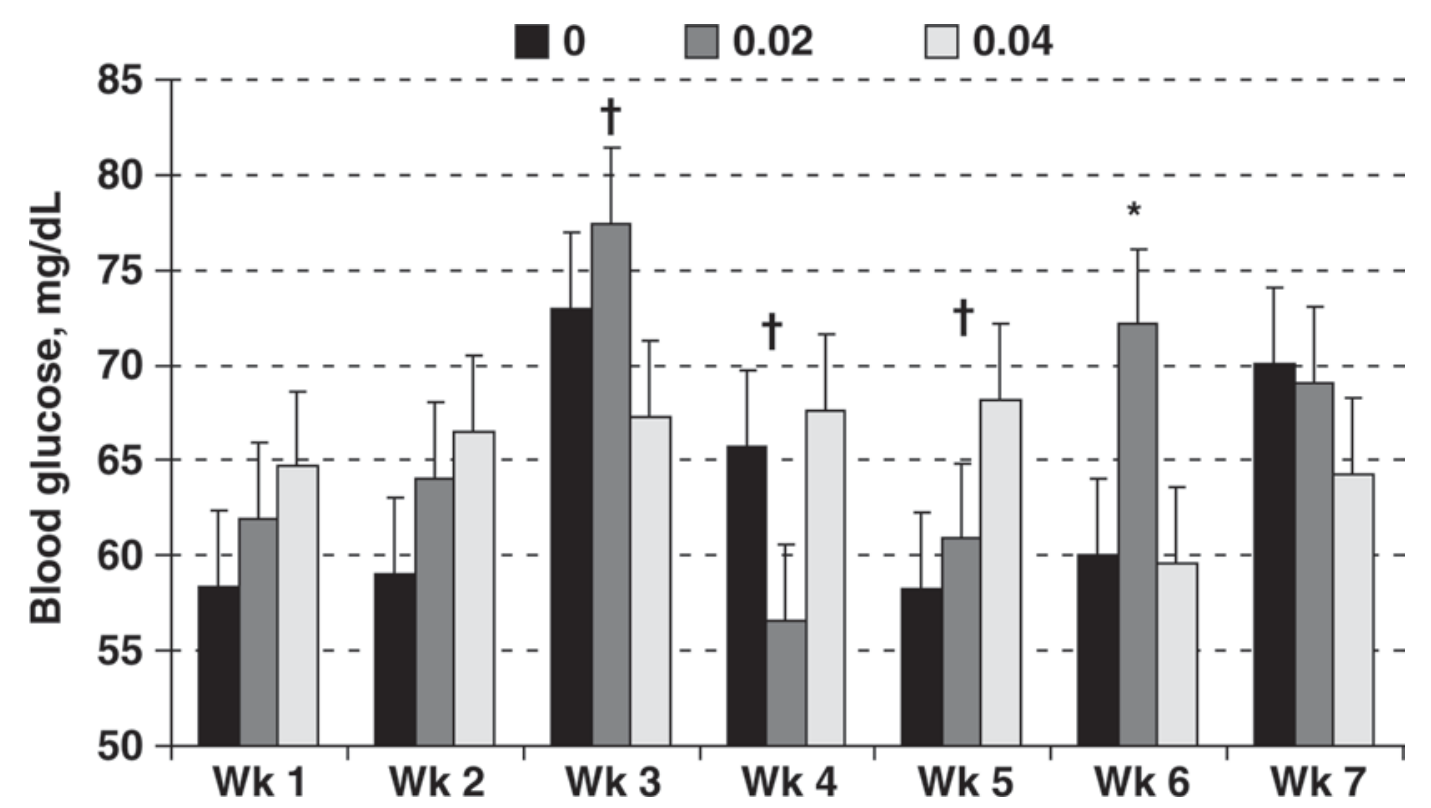

Figure 1. Blood concentrations of glucose in Holstein calves fed either no, 0.02 , or $0.04 \mathrm{mg} / \mathrm{kg}$ of BW $\mathrm{W}^{0.75}$ supplemental chromium, from wk 1 until weaning. Wk 3 : 0.02 vs. $0.04, P=0.08$. Wk $4: 0.02$ vs. $0.04, P=0.06$. Wk $5: 0$ vs. $0.04, P=0.09$. Wk $6: 0.02$ vs. 0 and $0.04, P=0.04$. 
Table 6. Effects of increased Cr supply on blood metabolites and hormones on d 21 postweaning of Holstein calves

\begin{tabular}{|c|c|c|c|c|c|c|c|c|}
\hline Metabolite & \multicolumn{3}{|c|}{ Supplemental Cr, mg/kg of BW ${ }^{0.75}(\mathrm{~T})$} & SEM & \multicolumn{4}{|c|}{$P$-value } \\
\hline Glucose, mg/dL & 67.4 & 67.4 & 60.6 & 4.1 & 0.29 & 0.53 & 0.80 & 0.82 \\
\hline Glucose:insulin & 11.1 & 10.8 & 10.1 & 1.0 & 0.52 & 0.64 & 0.88 & 0.84 \\
\hline Cortisol, $\mu \mathrm{g} / \mathrm{dL}$ & 1.87 & 2.36 & 2.23 & 0.10 & 0.02 & 0.003 & 0.003 & 0.95 \\
\hline Thyroxin, ${ }^{1} \mu \mathrm{g} / \mathrm{dL}$ & 5.50 & 5.07 & 5.13 & 0.16 & 0.12 & 0.05 & 0.46 & 0.08 \\
\hline Albumin, $\mathrm{g} / \mathrm{dL}$ & 4.01 & 4.11 & 4.12 & 0.15 & 0.63 & 0.58 & 0.93 & 0.03 \\
\hline Globulin, g/dL & 3.80 & 3.79 & 3.81 & 0.19 & 0.96 & 0.99 & 0.14 & 0.51 \\
\hline Albumin:globulin & 1.17 & 1.09 & 1.08 & 0.15 & 0.68 & 0.64 & 0.34 & 0.48 \\
\hline Urea $\mathrm{N}, \mathrm{mg} / \mathrm{dL}$ & 4.2 & 4.9 & 4.5 & 0.4 & 0.62 & 0.36 & 0.18 & 0.24 \\
\hline BHBA, mmol/L & 0.38 & 0.33 & 0.35 & 0.02 & 0.40 & 0.17 & 0.75 & 0.08 \\
\hline NEFA, $\mu \mathrm{mol} / \mathrm{L}$ & 211.9 & 210.7 & 211.2 & 11.0 & 0.96 & 0.94 & 0.80 & 0.22 \\
\hline
\end{tabular}

${ }^{\mathrm{a}, \mathrm{b}}$ Different superscripts within a row indicate statistical significance at $P<0.05$.

${ }^{1}$ For 0 vs. $0.02, P=0.07$.

tisol concentrations were higher $(P<0.05)$ at $0.02 \mathrm{mg}$ compared with $0.04 \mathrm{mg}$ of $\mathrm{Cr} / \mathrm{kg}$ of $\mathrm{BW}^{0.75}$, whereas at wk 5, receiving $0.02 \mathrm{mg}$ compared with either 0 or 0.04 $\mathrm{mg}$ of $\mathrm{Cr}$ led to higher blood cortisol $(P<0.01)$. At wk 3 and 6 , male calves on $0.02 \mathrm{mg}$ of supplemental $\mathrm{Cr} /$ $\mathrm{kg}$ of $\mathrm{BW}^{0.75}$ had greater blood cortisol concentrations than control males $(P<0.05)$, but at wk 7 , it was only the higher $\mathrm{Cr}$ dose that could increase blood cortisol $(P$ $<0.001$ ). At $21 \mathrm{~d}$ postweaning, blood cortisol exhibited a quadratic response $(P=0.003)$ to increased $\mathrm{Cr}$ supply, with the lower dose increasing it. Moonsie-Shageer and Mowat (1993) reported that supplemental Cr under transportation stress in the diets of feeder calves lowered blood cortisol concentrations and morbidity; however, other studies were unable to confirm this response (Mowat et al., 1993; Chang et al., 1995). Kegley and Spears (1995) reported that Cr-nicotinic acid or Cr-chloride decreased serum cortisol, but Depew et al. (1998) found no effects of Cr-picolinate on preweaning serum cortisol. Coleman et al. (1996) found no effects of medium heat stress ( $\mathrm{THI}=78$ to 79 ) on serum cortisol concentrations in preweaning dairy calves. The present study is the first to find that increased Cr supply in summer under high AT can increase blood cortisol in pre- and postweaning calves. Such an increase has previously been reported only in pigs fed Cr-nicotinic acid (van Heugten and Spears, 1997). Increased circulating cortisol levels by increasing Cr supply may enable the animal to more effectively cope with environmental stressors. Reduced RR near weaning when calves shift from milk into solid and fibrous feeds may have been achieved in part by the increased peripheral cortisol levels. This would suggest that blood cortisol acts as an alarm and enables the body to overcome unfavorable conditions (van Heugten and Spears, 1997). Female calves had greater blood cortisol compared with male calves at $21 \mathrm{~d}$ postweaning $(2.35$ vs. $1.95 \mu \mathrm{g} / \mathrm{dL} ; P<$ $0.01)$. In view of the females' lower growth, higher blood cortisol levels might be considered a more pronounced effect of high AT on maintenance energy use and growth performance when compared with male calves.

Among the approaches to help overcome high AT is to relatively depress thyroid hormones in an effort to lower basal metabolism rate (Baccari et al., 1983;

Table 7. Effects of increased Cr supply on serum glucose and insulin kinetics following an intravenous glucose tolerance test on d 25 postweaning of Holstein calves

\begin{tabular}{|c|c|c|c|c|c|c|c|c|}
\hline \multirow{2}{*}{$\begin{array}{l}\text { Area } \\
\text { under curve }\end{array}$} & \multicolumn{3}{|c|}{ Supplemental $\mathrm{Cr}, \mathrm{mg} / \mathrm{kg}$ of $\mathrm{BW}^{0.75}(\mathrm{~T})$} & \multirow[b]{2}{*}{ SEM } & \multicolumn{4}{|c|}{$P$-value } \\
\hline & 0 & 0.02 & 0.04 & & Linear & Quadratic & $\operatorname{Sex}(S)$ & $\mathrm{S} \times \mathrm{T}$ \\
\hline \multicolumn{9}{|l|}{ Glucose } \\
\hline $0-60 \mathrm{~min}$ & 5,024 & 4,800 & 4,862 & 190 & 0.56 & 0.43 & 0.76 & 0.97 \\
\hline 0-90 min & 7,726 & 7,175 & 7,283 & 293 & 0.31 & 0.19 & 0.43 & 0.92 \\
\hline $0-120 \min$ & 10,282 & 9,745 & 9,998 & 500 & 0.70 & 0.52 & 0.16 & 0.74 \\
\hline \multicolumn{9}{|l|}{ Insulin } \\
\hline $0-60 \mathrm{~min}$ & 733 & 614 & 640 & 57 & 0.30 & 0.19 & 0.92 & 0.59 \\
\hline 0-90 min & 1,126 & 899 & 809 & 78 & 0.02 & 0.03 & 0.91 & 0.55 \\
\hline $0-120 \min$ & 1,490 & 1,270 & 1,075 & 95 & 0.02 & 0.03 & 0.55 & 0.26 \\
\hline
\end{tabular}




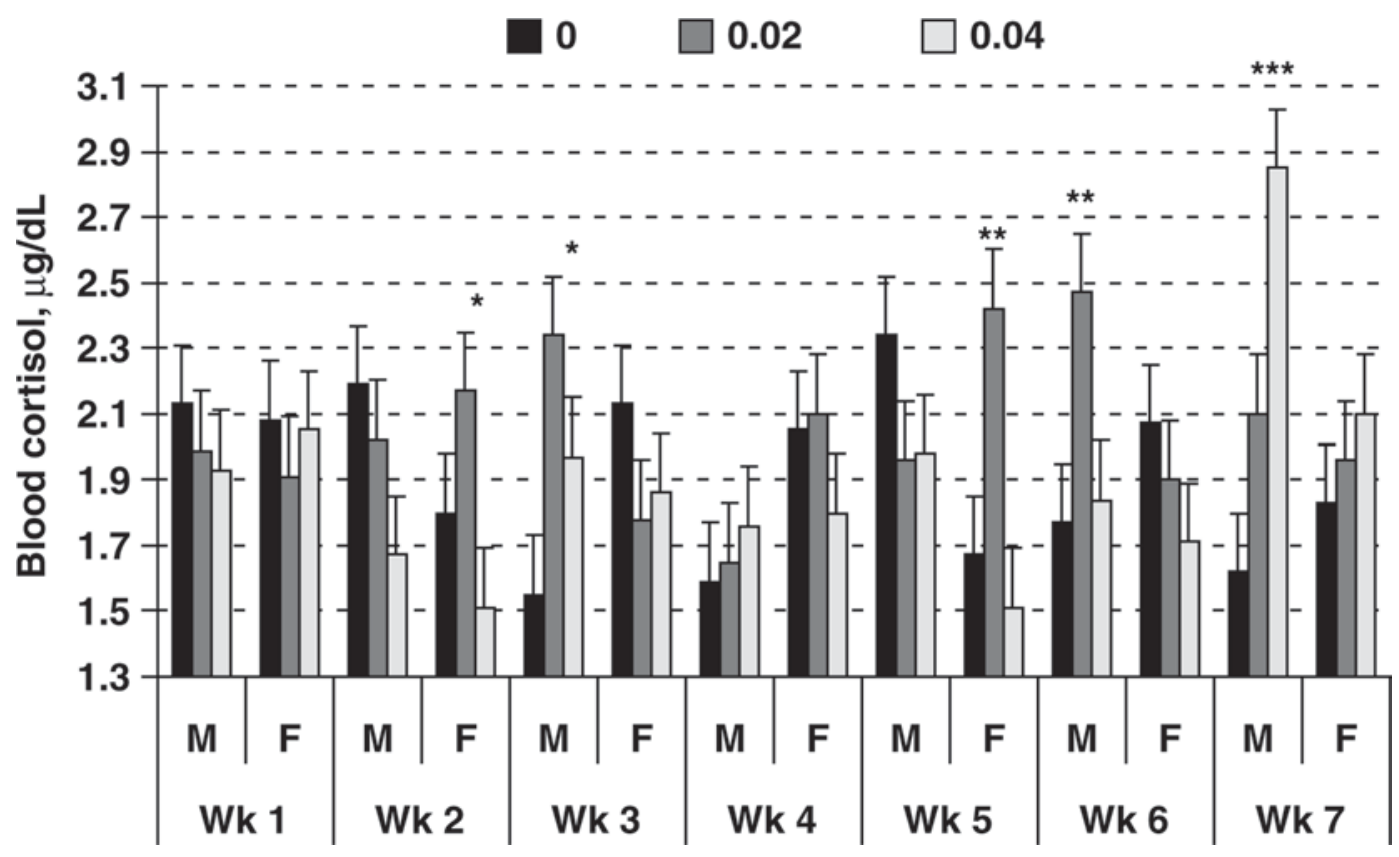

Figure 2. Blood concentrations of cortisol in male (M) and female (F) Holstein calves fed either no, 0.02, or $0.04 \mathrm{mg} / \mathrm{kg}_{\mathrm{g}}$ of BW $\mathrm{B}^{0.75} \mathrm{supple-}$ mental chromium, from wk 1 until weaning. Wk $2-\mathrm{F}$ : 0.02 vs. $0.04, P<0.05$. Wk $3-\mathrm{M}$ : 0 vs. $0.02, P<0.05$. Wk $5-\mathrm{F}$ : 0.02 vs. 0 and $0.04, P<$ 0.01 . Wk $6-\mathrm{M}: 0$ vs. $0.02, P<0.05$. Wk $7-\mathrm{M}: 0$ vs. $0.04, P<0.001$.

Sahin et al., 2002), which might or might not lead to relative reductions in animal growth. Although blood concentrations of $\mathrm{T}_{3}$ and $\mathrm{T}_{4}$ did not change through weaning (Table 5), at $21 \mathrm{~d}$ postweaning, increased $\mathrm{Cr}$ supply quadratically decreased blood $\mathrm{T}_{4}(P<0.05)$ whereas a numerical decrease in blood $\mathrm{T}_{3}$ occurred only with the higher $\mathrm{Cr}$ dose (Table 6). A decrease in blood $\mathrm{T}_{3}$ has been reported in heat-stressed calves (Baccari et al., 1983). Blood $\mathrm{T}_{3}: \mathrm{T}_{4}$ ratio was greater at $0.02 \mathrm{mg}$ of $\mathrm{Cr}$ compared with at 0 or $0.04 \mathrm{mg}$ of supplemental Cr $(P<0.05)$. To become functional, $\mathrm{T}_{4}$ needs to be converted to $\mathrm{T}_{3}$. As a result, a more biologically meaningful relationship is expected between growth and $\mathrm{T}_{3}$ rather than $\mathrm{T}_{4}$ (Kahl et al., 1977). The $\mathrm{T}_{3}: \mathrm{T}_{4}$ ratio could indicate the efficiency of $\mathrm{T}_{4}$ to $\mathrm{T}_{3}$ conversion. The increased $\mathrm{T}_{3}: \mathrm{T}_{4}$ ratio at $0.02 \mathrm{mg}$ of supplemental $\mathrm{Cr} /$ $\mathrm{kg}$ of $\mathrm{BW}^{0.75}$ suggests an improvement in the efficiency of the $T_{4}$ conversion to $T_{3}$ and possibly an increased $T_{3}$ requirement for calves during summer.

Blood levels of TP and albumin are longer term indicators of AA and immune states, whereas blood urea may more accurately reflect short-term dietary effects on rumen ammonia production and hepatic $\mathrm{N}$ turnover (Kitchalong et al., 1995; NRC, 2001; Jahani-Moghadam et al., 2009). As such, blood globulin and the albumin to globulin ratio $(\mathbf{A}: \mathbf{G})$ are used to assess the systemic immune function at times of high metabolic demands. Neither metabolite was affected by treatments during the preweaning phase (Table 6). However, an interac- tion trend among $\mathrm{Cr}$ dose, sex, and preweaning week was found for A:G $(P<0.10)$ such that at wk 2 , males on $0.04 \mathrm{mg}$ of $\mathrm{Cr} / \mathrm{kg}$ of $\mathrm{BW}^{0.75}$ tended to have higher blood A:G than males on $0.02 \mathrm{mg}$ of $\mathrm{Cr} / \mathrm{kg}$ of $\mathrm{BW}^{0.75}$ (Figure 3). At wk 7, on the other hand, male calves on $0.04 \mathrm{mg}$ of supplemental $\mathrm{Cr} / \mathrm{kg}$ of $\mathrm{BW}^{0.75}$ tended to exhibit lower A:G than control males (Figure 3). This suggests greater male rather than female sensitivity to increased $\mathrm{Cr}$ supply in regulating hepatic protein turnover and systemic immune function when high AT coincided with digestive and metabolic transitions of periweaning calves. In addition, at $21 \mathrm{~d}$ postweaning, interactions existed between $\mathrm{Cr}$ and calf sex on blood $\mathrm{TP}$ and albumin $(P<0.05)$. Blood albumin was greater in males at $0.02 \mathrm{mg}$ of $\mathrm{Cr} / \mathrm{kg}$ of $\mathrm{BW}^{0.75}$ than in control males $(P<0.05)$, whereas in females the lower $\mathrm{Cr}$ dose tended to decrease blood albumin compared with control or the higher $\mathrm{Cr}$ dose $(P \leq 0.10)$. The greater growth rate in male than in female calves suggests an increased demand and competition for AA and, thus, a challenge to hepatic synthesis of albumin, needed to sustain nutrient transportation and normal immune function. As such, Cr was expected to more noticeably contribute to boosting albumin status in male calves. Overall, these data suggest gender-dependent effects of $\mathrm{Cr}$ on calf immunity that may not only or necessarily represent tissue mass growth effects.

Based on the GGT data, Cr improved insulin efficiency. This could mean facilitating AA, acetate, and 


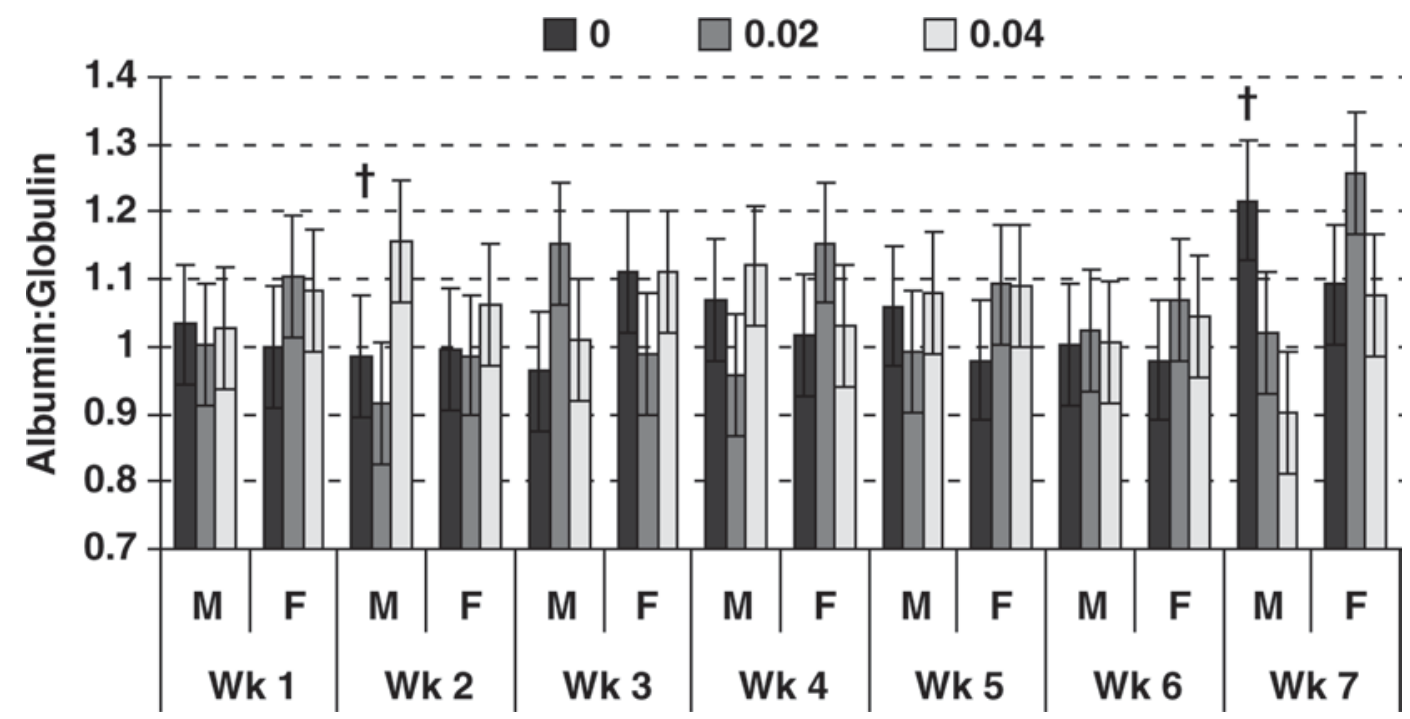

Figure 3. Blood ratio of albumin to globulin in male (M) and female (F) Holstein calves fed either no, 0.02, or $0.04 \mathrm{mg} / \mathrm{kg}^{\mathrm{s}}$ of BW $\mathrm{K}^{0.75} \mathrm{supple-}$ mental chromium, from wk 1 until weaning. Wk $2-\mathrm{M}$ : 0.02 vs. $0.04, P<0.10$. Wk $7-\mathrm{M}: 0$ vs. $0.04, P<0.10$.

glucose uptake by peripheral growing tissues. Serum NEFA and BHBA did not show main treatment or sex effects $(P<0.10$; Table 6$)$. However, treatments interacted with calf sex on blood BHBA such that in male and not in female calves, supplemental $\mathrm{Cr}$ decreased blood BHBA at $21 \mathrm{~d}$ postweaning (Figure 4). This was in agreement with Yang et al. (1996) observing a decline in plasma BHBA in cows fed sup- plemental AA-chelated $\mathrm{Cr}$ and suggests an increased peripheral BHBA use, probably by enhancing insulin function. The latter gains support from the reduced AUC for insulin during GTT. In addition, it is possible that the decreased postweaning DMI by Cr may have in part contributed to reduced blood BHBA by reducing the rumen wall production and portal supply of BHBA.

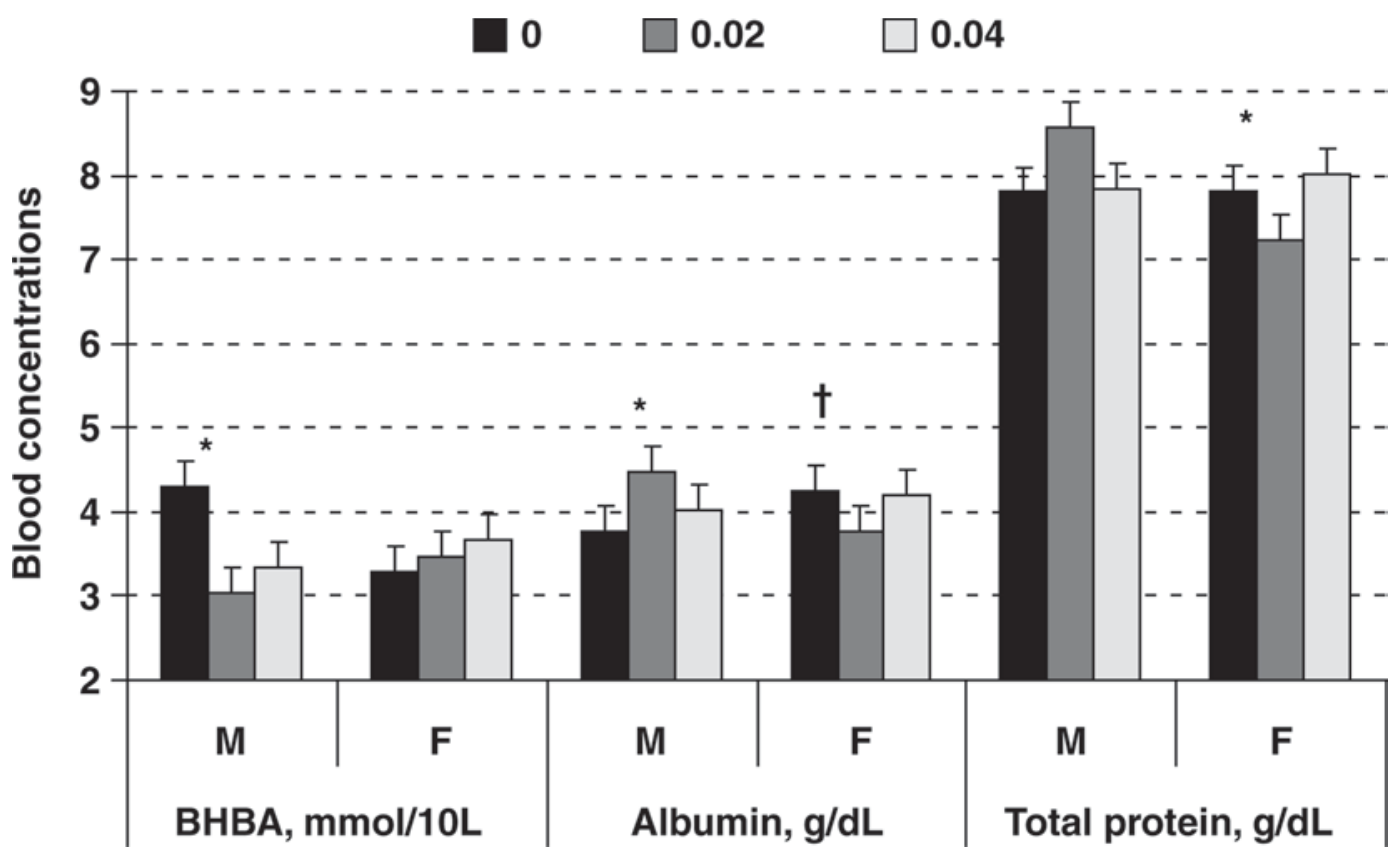

Figure 4. Blood concentrations of BHBA, albumin, and total proteins on d 21 postweaning in male (M) and female (F) Holstein calves fed either no, 0.02 , or $0.04 \mathrm{mg} / \mathrm{kg}$ of $\mathrm{BW}^{0.75}$ supplemental chromium. BHBA-M: 0 vs. $0.02, P<0.05 ; 0$ vs. $0.04, P=0.08$. Albumin-M: 0 vs. 0.02 , $P<0.05$. Albumin-F: 0 vs. $0.02, P=0.07 ; 0.02$ vs. $0.04, P=0.10$. Total protein-F: 0.04 vs. $0.02, P<0.05$. 


\section{CONCLUSIONS}

In summer and under high AT, increased Cr supply did not affect preweaning DMI and pre- and postweaning growth rate but decreased postweaning DMI. Chromium improved insulin function and altered glucose status. Preweaning blood glucose, but not insulin, concentrations showed week-dependent changes. On d 25 postweaning, an intravenous GTT revealed linear reductions in AUC of insulin during 0 to 90 and 0 to 120 min after glucose infusion, suggesting an improvement in peripheral insulin efficiency. Chromium altered blood cortisol through an interaction with calf sex and age through weaning and quadratically reduced blood $\mathrm{T}_{3}$ concentrations at $21 \mathrm{~d}$ postweaning. Blood albumin increased and BHBA decreased in male calves in response to supplemental Cr. Male rather than female calves tended to show a time-related response in blood $\mathrm{A}: \mathrm{G}$ in response to $\mathrm{Cr}$ supplementation. At wk 5 of age, $\mathrm{Cr}$ reduced respiration rate that suggested an attenuated external stress. Altogether, findings suggest beneficial $\mathrm{Cr}$ effects on the metabolism of postweaning calves receiving supplemental $\mathrm{Cr}$ periweaning.

\section{REFERENCES}

Al-Saiadi, M. Y., M. A. Al-Shaikh, S. I. Al-Mofarrej, T. A. Al-Showeimi, H. H. Mogawer, and A. Dirrar. 2004. Effect of chelated chromium supplementation on lactation performance and blood parameters of Holstein cows under heat stress. Anim. Feed Sci. Technol. 117:223-233.

Anderson, R. A. 1987. Chromium. Pages 225-244 in Trace Elements in Human and Animal Nutrition. Vol. 1. 5th ed. W. Mertz, ed. Academic Press Inc., New York, NY.

AOAC. 2002. Official Methods of Analysis. 16th ed. Assoc. Offic. Anal. Chem., Arlington, VA.

Baccari, F., H. D. Johnson, and G. L. Hahn. 1983. Environmental heat effects on growth, plasma TG, and postheat compensatory effects on Holstein calves. Proc. Soc. Exp. Biol. Med. 173:312-318.

Bunting, L. D., T. A. Tarifa, B. T. Crochet, J. M. Fernandez, C. L. Depew, and J. C. Lovejoy. 2000. Effects of dietary inclusion of chromium propionate and calcium propionate on glucose disposal and gastrointestinal development in dairy calves. J. Dairy Sci. 83:2491-2498.

Chang, X., D. N. Mowat, and B. A. Mallard. 1995. Supplemental chromium and niacin for stressed feeder calves. Can. J. Anim. Sci. $75: 351-358$.

Coleman, D. A., B. R. Moss, and T. A. Mccaskey. 1996. Supplemental shade for dairy calves reared in commercial calf hutches in a southern climate. J. Dairy Sci. 79:2038-2043.

Depew, C. L., L. D. Bunting, J. M. Fernandez, D. L. Thompson Jr., and R. W. Adkinson. 1998. Performance and metabolic responses of young dairy calves fed diets supplemented with chromium tripicolinate. J. Dairy Sci. 81:2916-2923.

García-Ispierto, I., F. Lopez-Gatius, P. Santolaria, J. L. Yaniz, C. N. Nogareda, M. Lopez-Bejar, and F. De Renesis. 2006. Relationship between heat stress during the peri-implantation period and early fetal loss in dairy cattle. Theriogenology 65:799-807.

Hayirli, A., D. R. Bremmer, S. J. Bertics, M. T. Socha, and R. R. Grummer. 2001. Effect of chromium supplementation on production and metabolic parameters in periparturient dairy cows. J. Dairy Sci. 84:1218-1230.

Hostettler-Allen, R. L., L. Tappy, and J. W. Blum. 1994. Insulin resistance, hyperglycemia, and glucosuria in intensively milkfed calves. J. Anim. Sci. 72:160-173.
Hugi, D., R. M. Bruckmaier, and J. W. Blum. 1997. Insulin resistance, hyperglycemia, glucosuria, and galactosuria in intensively milk-fed calves: Dependency on age and effects of high lactose intake. J. Anim. Sci. 75:469-482.

Iranian Council of Animal Care. 1995. Guide to the Care and Use of Experimental Animals. Vol. 1. Isfahan University of Technology, Isfahan, Iran.

Jahani-Moghadam, M., H. Amanlou, and A. Nikkhah. 2009. Metabolic and productive response to ruminal protein degradability in early lactation cows fed untreated or xylose-treated soybean mealbased diets. J. Anim. Physiol. Anim. Nutr. doi:10.1111/j.14390396.2008.00867.x

Johnson, H. D. 1987. Bioclimates and livestock: Bioclimatology and the adaptation of livestock. World Anim. Sci. 21:140-151.

Kahl, S., T. R. Wrenn, and J. Bitman. 1977. Plasma tri-iodothyronine and thyroxine in young growing calves. J. Endocrinol. 73:397-398.

Kegley, E. B., D. L. Galloway, and T. M. Fakler. 2000. Effect of dietary chromium-L-methionine on glucose metabolism of beef steers. J. Anim. Sci. 78:3177-3183.

Kegley, E. B., and J. W. Spears. 1995. Immune response, glucose metabolism and performance of stressed feeder calves fed inorganic or organic chromium. J. Anim. Sci. 73:2721-2726.

Kitchalong, L., J. M. Fernandez, L. D. Bunting, L. L. Southern, and T. D. Binder. 1995. Influence of chromium tripicolinate on glucose metabolism and nutrient partitioning in growing lambs. J. Anim. Sci. 73:2694-2705.

Larson, L. L., F. G. Owen, J. L. Albright, R. D. Appleman, R. C. Lamb, and L. D. Muller. 1977. Guidelines toward more uniformity in measuring and reporting calf experimental data. J. Dairy Sci. 60:989-991.

Littell, R. C., G. A. Milliken, W. W. Stroup, R. D. Wolfinger, and O. Schabenberger. 2006. SAS for Mixed Models. SAS Institute Inc. Cary, NC.

Moonsie-Shageer, S., and D. N. Mowat. 1993. Effect of level of supplemental chromium on performance, serum constituents and immune status of stress feeder calves. J. Anim. Sci. 71:232-238.

Mowat, D. N. 1997. Organic Chromium in Animal Nutrition. Chromium Books, Guelph, Ontario, Canada.

Mowat, D. N., X. Chang, and W. Z. Yang. 1993. Chelated chromium for stressed feeder calves. Can. J. Anim. Sci. 73:49-55.

Nikkhah, A., M. Mirzaei, M. Khorvash, H. R. Rahmani, and G. R. Ghorbani. 2010. Chromium improves production and alters metabolism of early lactation cows in summer. J. Anim. Physiol. Anim. Nutr. (Berl.) doi:10.1111/j.1439-0396.2010.01007.x

NRC. 1997. The Role of Chromium in Animal Nutrition. National Academy Press, Washington, DC.

NRC. 2001. Nutrient Requirements of Dairy Cattle. 7th rev. ed. National Acad. Sci., Washington, DC.

Sahin, K., O. Ozbey, M. Ondericikim, and M. H. Aysondu. 2002. Chromium supplementation can alleviate negative effects of heat stress on egg production, egg quality and some serum metabolites of laying Japanese quail. J. Nutr. 132:1265-1268.

SAS Institute. 2003. SAS Users' Guide. Version 9.1. SAS Institute Inc., Cary, NC.

Subiyatno, A., D. N. Mowat, and W. Z. Yang. 1996. Metabolite and hormonal responses to glucose or propionate infusions in periparturient dairy cows supplemented with chromium. J. Dairy Sci. 79:1436-1445.

van Heugten, E., and J. W. Spears. 1997. Immune response and growth of stressed weanling pigs fed diets supplemented with organic or inorganic forms of chromium. J. Anim. Sci. 75:409-416.

Vincent, J. B. 2000. The biochemistry of chromium. J. Nutr. 130:715718.

Vincent, J. B. 2001. The bioinorganic chemistry of chromium(III). Polyhedron 20:1-26.

Wang, Z., and L. A. Goonewardene. 2004. The use of MIXED models in the analysis of animal experiments with repeated measured data. Can. J. Anim. Sci. 84:1-11.

Yang, W. Z., D. N. Mowat, A. Subiyatno, and R. M. Liptrap. 1996. Effects of chromium supplementation on early lactation performance of Holstein cows. Can. J. Anim. Sci. 76:221-230. 